\title{
Human Resource Management Practices Perception and Career Success: The Mediating Roles of Employability and Extra-Role Behaviors
}

\author{
Maria Luisa Giancaspro ${ }^{1}\left(\mathbb{D}\right.$, Amelia Manuti $^{1, *(\mathbb{D}}$, Alessandro Lo Presti $^{2}\left(\mathbb{D}\right.$ and Assunta De Rosa ${ }^{2}(\mathbb{D})$ \\ 1 Department of Education, Psychology, Communication, University of Bari, 70121 Bari, Italy; \\ maria.giancaspro@uniba.it \\ 2 Department of Psychology, University of Campania "Luigi Vanvitelli", 81100 Caserta, Italy; \\ alessandro.lopresti@unicampania.it (A.L.P.); susi_derosa@yahoo.it (A.D.R.) \\ * Correspondence: amelia.manuti@uniba.it
}

Citation: Giancaspro, M.L.; Manuti, A.; Lo Presti, A.; De Rosa, A. Human Resource Management Practices Perception and Career Success: The Mediating Roles of Employability and Extra-Role Behaviors. Sustainability 2021, 13, 11834. https://doi.org/ $10.3390 /$ su132111834

Academic Editor: Lucian-Ionel Cioca

Received: 22 September 2021

Accepted: 22 October 2021

Published: 26 October 2021

Publisher's Note: MDPI stays neutral with regard to jurisdictional claims in published maps and institutional affiliations.

Copyright: (c) 2021 by the authors. Licensee MDPI, Basel, Switzerland. This article is an open access article distributed under the terms and conditions of the Creative Commons Attribution (CC BY) license (https:/ / creativecommons.org/licenses/by/ $4.0 /)$.

\begin{abstract}
Over the last decades, growing interest has been devoted to employees' perceptions of Human Resource Management Practices because of their positive influence on individual attitudes and behaviors as well as on organizational performance. Furthermore, assuming the mutual benefits coming from a people-based management of the human capital in organizations, both in terms of employees' increased motivation, engagement and commitment, and consequently enhanced performance and competitive advantage, recent research in the field concentrated on the impact of HRM practices perceptions on some distinctive individual attitudes and behaviors driving the success of organizations especially in times of radical change like the present ones. Moving from these assumptions, the aim of the present study was to examine the relationship between HRM practices perception and objective career success, considering the mediating role played by employability and extra-role behaviors. Participants were 960 Italian employees who filled an online self-report questionnaire available through the web platform Google Forms. The questionnaire encompassed socio-demographic information and self-report scales assessing the study variables. Results showed that HRM practices perception was positively related to employability, objective career success, and extra-role behaviors. Implications for theory and practice, limitations, and future research directions were also discussed.
\end{abstract}

Keywords: HRM practices; employability; career success; extra-role behaviors; organizational competitive advantage

\section{Introduction}

Human resource management is a complex organizational practice mostly inspired by two different models: a hard and a soft one [1]. These are based on opposing views of managerial control strategies and consequently of people in organizations. The hard model is based on notions of tight strategic control, and an economic model of man, while the soft model encompasses control through commitment and a people-based management of the human capital. Empirical evidence for both approaches converge over the undebatable value of people in organizations. According to some key contributions [2,3] the main distinction between the two perspectives, while considering people in organizations, is whether the emphasis is placed on people or resources.

Hard HRM focuses on a business-strategic management of people stemming out from a rationalistic and utilitaristic resource-based view of the organizational system [4,5]. Therefore, HRM is a crucial function within the organizational chart engaged in designing policies and practices to manage people that could best fit to the strategic objectives of the organization, thus finally increasing its competitive advantage on the market. In this perspective, human resources are a meaningful part of the asset of the organization together with other kinds of resources (e.g., financial, instrumental). 
On the other hand, soft HRM, originating from the Human Relations movement, proposes to adopt a "high-commitment" approach to human resources, creating the conditions that might encourage employees to identify with the goals of the organization and to work accordingly accomplishing those goals and therefore fulfilling personal expectations and career goals [4-6]. Consequently, according to soft HRM, policies and practices are considered precious tools to motivate, to train, to engage and to retain an intangible but fundamental capital that could make the difference for the organization in contemporary fast-changing and challenging markets.

However, despite the diversity of terminologies used to define HRM, which is basically linked to the disciplinary domain that has influenced its interpretation, both approaches recognize, implicitly or explicitly, the centrality and value that human resources have for the success and survival of companies [5].

Accordingly, within the last decades, a new stream of research emerged in the field in the attempt to conciliate HRM with the wider framework of sustainability. In this vein, the concept of sustainability is interpreted both as a "means" to achieve the organizational objectives and as an "end" to design human-based HRM policies and practices that could help organizations in their goals [7-9]. According to Kramar [5], sustainable HRM could be defined as "the pattern of planned or emerging HR strategies and practices intended to enable the achievement of financial, social and ecological goals while simultaneously reproducing the HR base over a long term" (p. 1084).

Following this definition, Macke and Genari [10] confirmed the crucial role played by some concrete management practices that could contribute to create value, balancing the organizational need for the achievement of financial and reputational goals with the expectations developed by individuals in terms of career growth and motivation [11]. This is not a new assumption, since already the theory of social exchange [12] and the norm of reciprocity [13] contributed to show that social exchanges in the workplace tend to generate reciprocal obligations between employers and employees, where the actions of one party are subordinated to the actions of another [14]. In other words, employees who receive economic and/or socio-emotional rewards and benefits from their organizations generally feel obligated to reciprocate performing positive attitudes and/or behaviors [15,16], since they feel that the organization is investing in them and recognizes their contributions [17].

With specific reference to HRM practices, prior research in the field has suggested that employees having positive perceptions about the way this organizational function treats them (e.g., by granting support, communication, appropriate training, career opportunities) tend to exhibit extra-role behaviors [18-20], are more engaged [15], manifest lower levels of turnover intentions [21-23], and show higher affective commitment [24]. In a similar vein, another stream of research mostly focused on the individual perspective showed that a positive HRM practices perception could also positively impact on employees' perceptions about their career success, if training and career development and management initiatives proposed by the organization are valued by the workforce as opportunities to fulfil one's own career objectives [25-27]. Likewise, more recently a very interesting debate called "employability paradox" [28] emerged in the field analyzing the relationship between HRM practices perception and employees' employability, maintaining that to invest in practices and policies addressed to empower workforce's skills and expertise could be a double edged issue because often organizations investing in human capital to stay competitive on the market take the risk to lose their most talented workers that becoming employable might search for a better working context [29]. Yet, the debate is still open and there is no definite conclusion if employability is a mutual gain for individuals and organizations or a conflicting interest. However, recent empirical evidence coming from longitudinal studies showed that it could be a mediator of the HRM-commitment relationship, given that perceived investments in HR practices concur to promote feelings of employability, which in turn create workplace commitment [30]. In this vein, another interesting variable that was suggested to be related to career success is extra-role behavior, considering the latter a proactive voluntary behavior addressed to develop one's own career and to catch 
up the opportunities given by the organizations through HRM practices and initiatives [31]. Following these assumptions, it could be argued that organizations investing in HRM and granting individuals opportunities to manage and grow their human capital, would more probably contribute to empower workers' employability and to foster extra-role proactive behaviors aimed at catching those opportunities, finally resulting in an enhanced perception about their career success.

In view of the above, the present study aimed at contributing to extant literature by examining if and to what extent HRM practices could be related to employees' perception about their career success, specifically focusing on the role played by employability and extra-role behaviors as mediators.

\section{Conceptual Framework and Research Hypotheses Development}

\subsection{Human Resource Management Practices and Employability}

Among the most significant outcome that might derive from enlightened HRM practices, employability deserves a primary role [32]. Employability is a complex, relational, and multidimensional concept [33-35], commonly meant as an individual chance of employment in internal and/or external labor markets [36,37]. However, employability is not simply an individual resource, rather it could be interpreted as a precious asset of the organization as long as an employable workforce is flexible, is adaptable to change and to manage the unexpected challenges that organizations are called to cope with.

Accordingly, in defining employability within organizational contexts, van Dam and colleagues [38] referred to employability as "the attitudes of employees toward interventions aimed at increasing the organization's flexibility through developing and maintaining workers' employability for the organization" (p. 30). This assumption arose from the classic concept of employability understood as a set of employee personal resources including individual factors, such as essential attributes, competencies, skills, experiences, work knowledge base, adaptability and mobility, contextual factors, such as work culture and access to resources, and external factors, such as the characteristics of the labor market, the work environment, and organizational opportunities [39]. The link between employability and the working context overcomes the logic of conflicting outcome and embraces the logic of mutual gain [29]. Indeed, for many years researchers questioned the possibility of a return on investment in their employees' career development [28-41]. On the one hand, the evidence that more competent employees are more productive and make a stronger contribution to organizational performance [35], on the other hand, the fear that more competent employees could have stronger "possibilities of obtaining and maintaining employment" [42] (p. 594) and therefore more opportunities to find an alternative employment outside the organization.

According to this perspective, employability is a "shared responsibility between employees and employers [43] in which employers provide HRM policies and practices that stimulate employability and employees use these opportunities to become and remain employable" [29] (p. 1095). The importance of investing in HRM practices focused on the enhancement and growth of people lies in the fact that if employees perceive that such investments in human resources can improve their employability, this can create a mutual benefit through a process of social exchange. The use of these HR practices will help employees to improve their knowledge, to enhance their skills to feel more committed to the organizational goals and therefore to work better to contribute to organizational performance.

Prior research on HRM practices focused on the impact of HRM practices on employee and on organizational performance $[44,45]$. As to date, only a few studies have dealt with the relationship between HRM practices and employability. The study by Veld, Semeijn and colleagues [46] is one of the few and contributed to show that HRM practices supporting training, development and mobility were positively related to employability.

However, previous research had already highlighted how HRM practices, characterized by high-performance, high-involvement work systems, or high-commitment 
management practices [47], grant a competitive advantage to companies and also improve the results of individuals, in terms of trust in management, perceived safety, work engagement [48], and employability [49]. Given these premises, we formulated the following hypothesis:

Hypothesis 1a (H1a): HRM practices perception will be positively associated with employability.

\subsection{Human Resource Management Practices and Extra-Role Behaviors}

Several studies showed that HRM practices impact on employee performance and on the competitive advantage of an organization [50,51]. In this perspective, extra role behaviors could be considered as those positive behaviors of employees that could contribute to improving organizational effectiveness. Extra-role behaviors are a component of the wider construct of organizational citizenship behavior (OCB) defined by Organ [52] as "individual behaviour that is discretionary, not directly recognized by the formal reward system and that in the aggregate promotes the effective functioning of the organization" (p. 4). These behaviors, based on voluntary, extra-motivational and non-job position related activities for the benefit of the organization (e.g.,: support for other employees, showing initiative, observing the work ethics, etc.), represent a strategic resource for the organizations [53]; however, for these behaviors to occur, it is necessary that there are conditions and a work environment that favor them.

A crucial factor contributing to creating a work environment favorable to OCB is given by HRM practices. In particular, those practices aimed at increasing motivation and commitment to work, creating a professional atmosphere, as well as at assessment and training of staff, in addition to increasing organizational effectiveness, become significant antecedents for strengthening organizational citizenship behaviors [54,55]. Available evidence suggests that all activities which make up human resources management; therefore, recruitment and selection, motivation and reward, evaluation and development, may contribute to the emergence of citizenship behaviors [56-58]. Wei et al. [59] confirmed that employees who perceive HRM practices based on inclusion, participation, training, communication and fair incentive compensation may be more motivated to show their willingness to engage in extra-role (OCB) behaviors which were beneficial for their organizations. At the same time, Baptiste [60] highlighted that positive attitude towards the organization and employees' extra-role behaviors might occur in the presence of HRM practices that in turn might create the culture and positive work environment of organization [61]. Based on this evidence, we formulated the following hypothesis:

Hypothesis $\mathbf{1 b}(\mathbf{H 1 b})$ : HRM practices perception will be positively associated with extra-role behaviors.

\subsection{Human Resource Management Practices and Career Success}

Employability is not the only beneficial output of a strategic HRM plan. Another positive outcome that could be observed as a response to a sustainable management of people within organizations is career success.

The most traditional concept of objective career success implies occupational prestige and financial attainment specifically linked to upward mobility and increase in pay and benefits [62]. However, career success is also defined in terms of positive work-related outcomes associated with career experiences over time [63]. It is at the same time a subjective and organizational dimension: career success is a prerogative of individual workers engaged in maintaining employability to respond to the constant change of the labor market [64]. Accordingly, due to widespread globalization, rapid growth, and technological evolution, it is necessary to possess skills and abilities that make individuals attractive to today's organizations. However, career success is also an individual component as it is frequently associated with high performance and quality therefore organizations strive to hire and retain knowledge workers who possess unique skills and expertise [65]. 
HRM practices can impact positively on individuals' career perspectives and on the strategies workers adopt to develop them [66]. Within organizations where HRM practices are mainly addressed to skills development, employee growth, involvement in decisionmaking processes, and training of resources, employees will be more likely to be successful and individuals' career success will also more likely contribute to enhanced organizational performance [67]. Therefore, employees' career success has been proved to be a strategic factor in driving individual performance at work and consequently in sustaining organizational success as well $[26,68]$. Based on these assumptions, we proposed that

Hypothesis 1c (H1c): HRM practices perception will be positively associated with objective career success.

\subsection{Employability and Extra-Role Behaviors: The Effects on Career Success}

As argued earlier, career success is beneficial to both the individual and the organization, acting equally on individual motivation, and on organizational performance and strictly linked to a strategic HRM plan [63-70].

Accordingly, to Spurk and colleagues [71], who studied antecedents and outcomes of objective versus subjective career success, one theoretical explanation for between-person differences in career success is that people differ in the extent to which they can draw on personal and/or contextual resources to achieve their career success goals. Therefore, these resources, can be of an individual nature, such as knowledge, experience, awareness, but also self-esteem, optimism, or personality traits, and resources related to the company context, such as supervisor support, organizational policies, employment type, but also contextual macro-resources, such as culture, labor market, or social welfare systems [72].

In view of the above, the present study moved from the interest in investigating the individual and organizational antecedents of career success. Therefore, employability was considered as one of the most important elements that might determine an increase in the probability and perception of career success for employees. Employability and career success are clearly distinct constructs [35-73] because employability refers to the individual's present capacity to retain or to find new employment, while career success concerns actual or perceived career achievements over a long period of time. However, scientific contributions showed that they are placed in a causal relationship as showed by several studies underlining how employability might have career-enhancing properties [33-75].

In this vein, individuals who are employable are more likely to feel optimistic about their future work life and career prospects [76]. By this, as showed earlier employability is a precious feature not only for individuals but for organizations as well, especially in turbulent and changing times like the present ones. Yet, the importance of using talents and continuing to develop, expand, and refine one's skills, abilities, and talents are essential components of career and personal success as well as of organizational competitive advantage on the market.

Accordingly, as maintained by van der Heijde and van der Heijden [33], employability could predict career success. In fact, the authors found that all the five-dimensional conceptualization of employability were related to one or more objective (i.e., number of promotions in the company and in the entire career, monthly gross income, periods of unemployment) and subjective (i.e., job satisfaction, interpersonal, hierarchical, and financial career success, life satisfaction) feature of career success. Similar evidence was also found by Lo Presti and colleagues [77] who found employability predicted subsequent objective and subjective career success. In line with these premises, we proposed that

Hypothesis 2a (H2a): Employability will be positively associated with objective career success.

On the organizational side, as already showed, career success is determined by company choices regarding HR policies and practices. However, a crucial role in this relationship is given by employees' proactivity, visible in positive organizational behaviors that could concretely give them the opportunity to develop one's own career capitalizing 
the chances given by the organization through HRM practices. Among these positive organizational behaviors, a prominent role is played by extra-role behaviors. Extra-role behaviors include being helpful and supportive to juniors and colleagues, staying beyond working hours, paying attention to environments and spaces, keeping the workplace clean, avoiding waste of resources, and so on, which go to advantage of the organization.

Several scholars have stressed the importance of examining the need to understand how employees' work behaviors could contribute to increasing their professional success [78-80]. Studies carried out in various fields $[81,82]$ showed that proactive employees engaged in these kinds of behaviors are more prone to work effectively [83] and to achieve professional success [31-78,84,85].

Generally, scholars linked proactive and extra-role behaviors to positive individual and organizational outcomes (i.e., organizational effectiveness) such as earning higher salaries, demonstrating greater productivity, and receiving more awards and promotions or other career-advancing rewards [83]. Grant et al. [86] found that proactive behaviors contributed to higher supervisor performance evaluations, when employees express strong prosocial values. Ultimately, employees who commit voluntarily to the organization, engaging in a series of behaviors that benefit the company, feel they have more opportunities to enhance their skills, improve their job positions and be successful professional. Therefore, we hypothesized that

Hypothesis 2b (H2b): Extra-role behaviors will be positively associated with career success.

In light of these assumptions, the current study aimed to relate the variables considered to understand if and to what extent organizational or individual factors could more significantly predict career success. Specifically, on the one hand we hypothesized that when an organization adopts HR practices aimed at the enhancement and growth of employees, they will more probably perceive themselves more employable and consequently improve their perception of career success. On the other hand, it was contented that working in a context in which HR practices are centered on the person is useful to stimulate positive and prosocial behaviors towards the organization by employees and that this increases the perception of career success. Consequently, it was assumed that:

Hypothesis 3 (H3): Employability and extra-role behavior will mediate the associations between HRM practices perception and career success.

\section{Materials and Methods}

\subsection{Participants}

A convenience sample of Italian workers was involved; researchers contacted participants asking them to fill in an online self-report questionnaire composed by 31 items, during the period between February and May 2020. Participants were recruited through posts on social media like LinkedIn and were invited to fill the questionnaire. The questionnaire's cover sheet explained the anonymity (of both participants and their organizations), confidentiality and voluntariness of participation in the research. All participants provided their informed consent. The research observed the Helsinki Declaration (World Medical Association, 2013) and the General Data Protection Regulation.

The sample was made up of 960 Italian employees (46.5\% male; $53.5 \%$ female).

Mean age was 37.8 years $(\mathrm{SD}=12.89) .528$ employees $(55 \%)$ held a high-school degree, $318(33.1 \%)$ a university degree, and $114(11.9 \%)$ a post-graduate degree.

Average organizational tenure was 7.72 years $(\mathrm{SD}=9.47)$. A total of 693 employees (72.2\%) held a permanent employment contract, while $267(27.8 \%)$ a fixed-term contract. Moreover, 349 employees (36.4\%) worked in the public sector, while $611(63.6 \%)$ worked in the private one. 


\subsection{Measures}

After an accurate review of the literature, several concurring measures for the 4 variables considered in the model were analyzed. Accordingly, being HRM practices, Employability, Extra-role behavior, and Objective Career Success central constructs in most previous studies in W\&O Psychology as documented earlier, it exists a wide range of psychological concurring measures. The following ones were chosen because of their limited length, because of the clear formulation of the items and because of the good reliability proved in previous studies.

HRM Practices Perception were assessed through a 9-item (e.g., "I am provided with sufficient opportunities for training or development") scale by Gould-Williams and Davies [87]. Responses were collected through a 5-point scale from $1=$ not at all to $5=$ completely. Cronbach's alpha was 0.91 .

Employability was assessed through a 5-item (e.g., "My competence is sought-after in the labour market") scale by Berntson and Marklund [88]. Responses were collected through a 5-point scale from $1=$ not at all to $5=$ completely. Cronbach's alpha was 0.88 .

Extra-role behaviors were assessed through a 4-item (e.g., "I help other members of the organization in managing their responsibilities") scale by Podsakoff et al. [89]. Responses were collected through a 5-point scale from $1=$ not at all to $5=$ completely. Cronbach's alpha was 0.91 .

Objective career success was assessed through a 3-item (e.g., "my income increased") scale by Lo Presti and Elia [90] asking how successful the individual has been in the last ten years compared to his/her colleagues. Responses were collected through a 5-point scale from $1=$ much less than my colleagues to $5=$ much more than my colleagues. Cronbach's alpha was 0.87 . For each variable, global scores were computed summing its respective items' scores.

\subsection{Data Analysis}

No missing data treatment was needed. First, we tested if study variables were adequately distinct from each other and their measurement was not biased by, for instance, common method variance. Apart from $\chi^{2}$ values and degrees of freedom, we computed the following goodness of fit indices [91]: Root Mean Square Error of Approximation (RMSEA), Comparative Fit Index (CFI), Non-Normed Fit Index (NNFI), and Standardized Root Mean square Residual (SRMR). Moreover, $\Delta \chi^{2}$ test between nested models was used for comparing the relative improvement in terms of measurement adequacy of each model.

Cronbach's alphas and zero-order correlations were used to assess the scales' internal consistencies and examine associations between pairs of continuous variables. Finally, structural equational modeling was used to examine direct and indirect associations between variables, reporting standardized estimates.

The significance of the overall indirect effect can be found in the Lisrel output. For determining the significance of each specific indirect effect, we computed a Sobel test available at http:/ / quantpsy.org/sobel/sobel.htm (21 October 2021), using as starting values the $\mathrm{a}$ and $\mathrm{b}$ coefficients along with their standard errors.

\section{Results}

First, given that all variables were assessed at the same time, and common method variance could be a matter of concern, we computed different measurement models to verify if variables were clearly distinct from each other.

Before computing these models, we checked for items' asymmetry and kurtosis values. Asymmetry ranged between -0.87 and 0.39 , while kurtosis ranged between -1.26 and 0.06. We relied on Robust Maximum Likelihood estimation based on its better overall performance compared to Maximum Likelihood [92].

We initially estimated three different measurement models: M1 served as a baseline and included all scales' items loading on a whole factor, M2 included the scales' items loading on their respective scales (correlations between scales were fixed to zero), and 
finally, M3 was similar to M2 except for the correlations between items left free to be estimated. A closer examination to M3 highlighted four modification indexes that pertained to four couples of items' errors covariances (the four couples were: Perceived employability items \#1 and \#5 and items \#2 and \#3, extra-role behaviors items \#1 and \#4, human resource management practice items \#1 and \#2). All these couples referred to similar worded items within the same scale. Subsequently, a further measurement model, M4, including these four parameters, was estimated. Table 1 summarizes our findings.

Table 1. Measurement models goodness of fit indexes.

\begin{tabular}{ccccccc}
\hline Model & $\chi^{\mathbf{2}}$ & df & RMSEA & CFI & NNFI & SRMR \\
\hline M1 & 5505.07 & 189 & 0.189 & 0.59 & 0.54 & 0.140 \\
M2 & 1837.43 & 189 & 0.106 & 0.87 & 0.86 & 0.220 \\
M3 & 1251.61 & 183 & 0.089 & 0.92 & 0.90 & 0.055 \\
M4 & 628.34 & 179 & 0.059 & 0.96 & 0.96 & 0.050 \\
\hline
\end{tabular}

It can be noted a significant and progressive improvement from M1 to M4, passing through M2 and M3, so adequate empirical support for the variables' distinctiveness was proven and led to subsequent analyses.

HRM practices perception positively correlated with employability $(\mathrm{r}=0.40, p<0.001)$ and extra-role behaviors $(r=0.35, p<0.001)$; this latter positively correlated with employability $(\mathrm{r}=0.37, p<0.001)$.

Objective career success positively correlated with HRM practices perception $(\mathrm{r}=0.46$, $p<0.001)$, employability $(\mathrm{r}=0.41, p<0.001)$, and extra-role behaviors $(\mathrm{r}=0.31, p<0.001)$ (see Table 2).

Table 2. Depicts descriptive statistics and zero-order correlations between study variables.

\begin{tabular}{lcccc}
\hline & M (SD) & $\mathbf{1}$ & $\mathbf{2}$ & $\mathbf{3}$ \\
\hline (1) HRM practices perception & $27.15(8.93)$ & & & \\
(2) Employability & $15.96(5.14)$ & $0.40^{* * *}$ & & \\
(3) Extra-role behaviors & $15.05(4.17)$ & $0.35^{* * *}$ & $0.37^{* * *}$ & \\
(4) Objective career success & $7.74(3.53)$ & $0.46^{* * *}$ & $0.41^{* * *}$ & $0.31^{* * *}$ \\
\hline
\end{tabular}

Note: ${ }^{* * *} p<0.001$.

Thus, we estimated a structural model (based on M4 measurement model) encompassing the links from HRM practices perception to employability and extra-role behaviors, respectively, and from these latter variables to objective career success. This model showed adequate goodness of fit indexes $\left(\chi^{2}=715.13, \mathrm{df}=180, \mathrm{RMSEA}=0.063, \mathrm{CFI}=0.96\right.$, $\mathrm{NNFI}=0.95, \mathrm{SRMR}=0.072)$. However, a significant modification index suggested the HRM practices perception were also directly related to objective career success.

Subsequently, a further nested structural model was estimated including the direct link from HRM practices perception to objective career success. Goodness of fit indexes showed a clear improvement $\left(\chi^{2}=628.34, \mathrm{df}=179, \mathrm{RMSEA}=0.059, \mathrm{CFI}=0.96, \mathrm{NNFI}=0.96, \mathrm{SRMR}\right.$ $=0.050)$ than the previous structural model. Moreover, the $\chi^{2}(1)$ difference between the two models (86.79) was significant at $p<0.001$. Figure 1 depicts the definitive structural model.

HRM practices perception positively predicted employability $(\beta=0.46, p<0.001)$, extra-role behaviors $(\beta=0.36, p<0.001)$, and objective career success $(\beta=0.39, p<0.001)$. This latter was also positively predicted by employability $(\beta=0.24, p<0.001)$ and extra-role behaviors $(\beta=0.09, p<0.001)$. In regard to HRM practices perception's indirect effect, the total indirect effect $(a b)$ was $0.14(p<0.001)$, divided through employability $(a b=0.11$, $p<0.001)$ and extra-role behaviors $(a b=0.03, p=0.02)$. 


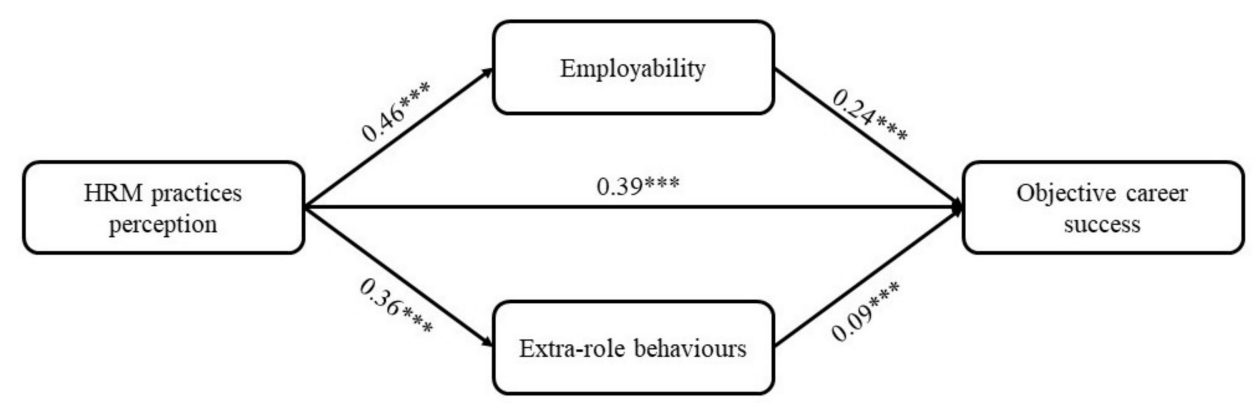

Figure 1. Structural model. Note: ${ }^{* *} p<0.001$.

Finally, in regard to mediators' and outcome's explained variance, HRM practices perception explained $21.3 \%$ of employability and $12.7 \%$ of extra-role behaviors' variances. Finally, the three abovementioned variables explained $34.2 \%$ of objective career success' variance.

\section{Discussion}

The aim of the study was to investigate the role played by employability and extrarole behaviors in the relationship between HRM practices perception and objective career success. Results provided significant suggestions that could be useful to develop future research and to draw practical implications in the field of human resources management, both from an individual and from an organizational point of view.

Study variables showed significant and moderate intercorrelations, thus, also taking into account the results from the initial CFA, demonstrating that we examined variables that were not overlapping with each other and, at the same time, were significantly associated and it was worth to examine. Following on this line, when it comes to the examination of the direct and indirect associations between these variables, predictors explained a significant, although not very high (especially in the case of extra-role behaviors), amount of outcomes' variables. It implies that future studies should include additional and concurrent predictors that may contribute in explaining additional variance as well as identifying alternative direct and indirect paths.

Nevertheless, results fully satisfied the research hypotheses formulated in the light of the literature. Hypothesis 1 was confirmed: HRM practices was proved to be positively related to employability (H1a), extra-role behavior ( $\mathrm{H} 1 \mathrm{~b})$, and objective career success (H1c). This result demonstrates how the positive perception of people-oriented and careeroriented HR practices can have a positive effect both on the perceived employability of employees, as confirmed by the longitudinal empirical data from Raeder et al. [93], suggesting that education, support for career and skill development, current level of jobrelated skills, and willingness to change jobs are significant predictors of employability. This evidence is aligned with the idea that beyond "personal" factors (agency), there is a strong relevance of contextual factors (structure) in influencing employability [94]. This means that all those practices that fall within sustainable HR practices, i.e., promoting employees' participation in formal and informal learning activities [95], or the participation in competency development initiatives, including mentoring and training, as well as organizational, supervisor and peer support for competency development, are associated with the development of employability competences [96].

H1b hypothesis was also confirmed: HRM practices perception had a positive effect on the extra-role behaviors of employees. Employees experiencing a working context where there was a particular attention to the development of positive and growth-oriented HR practices were more likely to engage in behaviors that were not required by the role and not strictly linked to work performance, but which were in favor of the organization and could contribute to increase its competitive advantage. Sound and effective HRM practices elicit and enhance a positive attitude and behavior among employees [97-99]. In other words, results suggested that those employees who had a positive attitude and high 
organizational commitment were most likely to spend their time and energy trying to help the organization in accomplishing its tasks and objectives [100]. These could be employees' positive behaviors in terms of innovation, creativity, commitment, and discretionary effort, which ultimately might enhance the financial status and the reputation of the organization on the market [101]. It is therefore essential to pay enough attention to the direct effect HRM practices might have on employees [48-103].

In the similar vein, HRM practices perception seemed to have a direct effect on objective career success of employees (H1c). HR practices considered in this study also included those oriented to employee career development, specifically related to the activities that companies carry out to sustain their employees' career development [104], helping them obtaining promotions and pay raises, and assisting their transition into leadership positions [105]. As already highlighted by [106], research and practice continued to stress the pivotal role that organizational people-based HR practices are assuming in the current scenario to face the challenges of people management in organizations $[107,108]$. The authors suggested that in recent years HR practices have increasingly addressed employees' career development, going beyond a traditional view of career success as increased pay or higher status [79] and mostly focusing on the development of personal skills such as proactivity, goal orientation, and employability [109,110].

Results also confirmed $\mathrm{H} 2$ predicting a positive impact of employability (H2a) and extra-role behaviors ( $\mathrm{H} 2 \mathrm{~b}$ ) on objective career success. Specifically, assuming that employability of workers could be achieved through the acquisition of knowledge, skills, abilities, and other characteristics that might determine an individual's career potential [33-35,111], employability was considered a determining factor for contemporary professional success [73]. As already demonstrated by van der Heijde and van der Heijden [35], employability predicts career success. In their study it is evident that all the dimensions that make up employability appear to be related to one or more objective career success (i.e., number of promotions in the company and in the entire career, monthly gross income, periods of unemployment) and subjective career success (i.e., job satisfaction, interpersonal, hierarchical, and financial career success, life satisfaction) facets. Similarly, even a more organizational variable such as extra-role behaviors represented a significant antecedent to career success. Previous studies showed that employees expressing stronger attachment to the organization, stronger commitment therefore tending to enact organizational citizenship behaviors were positively evaluated by their superiors and then had a greater chance of career advancement, to access benefits, and to obtain recognition [112]. Therefore, this relationship goes beyond the logic of formal recognition in the face of achieving in-role performance objectives but underlines how objective career success could be determined by a set of behaviors not strictly related to organizational performance rather to positive behavior for the benefit of colleagues and of the organization. These behavior includes assisting, cooperating, and accommodating colleagues, volunteering extra work, and sharing new and innovative ideas and fall within the organizational citizenship behavior that employees voluntarily implement as teamwork with employees, approaching workplace earlier and leaving late, helping other employees, using organizational possessions with care, disseminating positively in organization.

Finally, about H3, results confirmed the partial mediation of employability and extrarole behaviors in the relationship between HRM practices perception and objective career success. Regarding this latter evidence, it is interesting to note how people-based human resource management systems, namely, addressed to the development of employees' skills, could increase their levels of employability and in turn their levels of objective career success [31]. Accordingly, employees who recognized in HRM practices a particular attention to their career growth, through the availability of appropriate training and career advancements' opportunities, as well as the development of a fair evaluation system and an adequate reward system, would more probably be inclined to commit themselves to the organization with extra-role behaviors and this in turn would increase their chances of improving career success. This conclusion was further confirmed by a vast literature exam- 
ining employability from an organizational perspective and suggesting that a supportive context could foster employability [49-79].

\section{Limitations, Practical Implications, and Conclusions}

Notwithstanding the contribution given by the study in the field, some limitations could also be highlighted. A first limitation was related to the cross-sectional nature of the study that did not allow neither to test eventual causal relationship among variables nor to investigate them across time. Considering the changeability of the current labor market and of the constructs analyzed, it would have been interesting to verify the trend of these results over time through a longitudinal study that could have assessed the impact of other intervening variables.

Another limitation could be found in the limited and heterogeneous sample involved that cannot allow the generalization of results. The convenience sample set up through the online procedure did not allow to orient the collection by favoring some categories or checking some characteristics, therefore the sample was very heterogeneous both for different kind of professional categories (e.g., blue collar workers, white collar workers, managers), both for the different occupational sectors, in private and public contexts, and different kind of employment contracts with the organization (e.g., permanent and fixed-term).

Finally, another possible limitation of the study was related to the risk of commonmethod bias [113] and to the self-report measures. The first risk is generally associated with the use of common methods to measure multiple constructs (e.g., multiple-item scales presented within the same survey as in the present study) leading to spurious effects due to the measurement instruments rather than to the constructs being measured. This limitation could be addressed by future research adopting different scale endpoints and formats for the measures used. Moreover, to overcome the critical issues related to measurement through self-assessment, especially for the constructs analyzed in the study such as HRM practices, employability, extra-role behaviors, and career success, it could be useful to compare the perception of employees with more objective measures.

Despite these limitations, results from this study pointed out some interesting and valuable implications in terms of managerial practices. Yet, beside the perspective adopted on Human Resource Management, whether individual or organization, results fully confirmed the strategic value of people in organizations. Therefore, the lesson learnt was that to invest in HRM practices that focus on the added value of human capital for organizations means at the same time to have a motivated, committed, and efficient workforce that would more probably engage in extra-role behaviors and perform efficiently. Therefore, in a virtuous circle the return on investment made by the organization in training, career management opportunities, and welfare practices would be evident in the organizational success and performance with respect to competitors. These HR practices are what the literature defines as "sustainable" namely aimed at balancing the individual prerogatives linked to the need to enhance one's own employability and career success with the organizational goals addressed to win on the rivals and to stay competitive on the market.

In view of the above, a change of the traditional cultural paradigm of human resource management is needed, going beyond the interpretation of this strategic organizational function in terms of mere formal administration of roles and tasks to invest more on the relationship with the workforce, namely promoting practices and policies like organizational support, leadership, talent management, skill development, and communication [114]. As confirmed also by the results of the present study this could be probably the main challenge for the future of organizations wishing to keep their performance high even in difficult times like the post-pandemic ones [115]. 
Author Contributions: Conceptualization, M.L.G., A.M. and A.L.P.; Data curation, A.L.P. and A.D.R.; Formal analysis, A.D.R.; Funding acquisition, A.L.P.; Investigation, M.L.G. and A.M.; Methodology, M.L.G., A.M., A.L.P. and A.D.R.; Project administration, M.L.G. and A.M.; Software, A.L.P.; Supervision, M.L.G. and A.M.; Writing-original draft, M.L.G., A.M. and A.L.P.; Writing一review \& editing, A.D.R. All authors have read and agreed to the published version of the manuscript.

Funding: This research received no external funding.

Institutional Review Board Statement: Not applicable.

Informed Consent Statement: Informed consent was obtained from all subjects involved in the study.

Data Availability Statement: The data presented in this study are available on request from the corresponding author. The data are not publicly available due to privacy reasons.

Acknowledgments: The authors would like to thank the Italian research group "WiP" for the data collection and the scientific support given to this paper.

Conflicts of Interest: The authors declare no conflict of interest.

\section{References}

1. Truss, C.; Gratton, L.; Hope-Hailey, V.; McGovern, P.; Stiles, P. Soft and hard models of Human Resource Management: A re-appraisal. J. Manag. Stud. 1997, 34, 53-73. [CrossRef]

2. Guest, D.E. Human resource management and industrial relations. J. Manag. Stud. 1987, 24, 503-521. [CrossRef]

3. Storey, J. Developments in the Management of Human Resources; Blackwell: Oxford, UK, 1992; ISBN 978-0-631-18398-3.

4. Jackson, S.E.; Seo, J. The greening of strategic HRM scholarship. Organ. Manag. J. 2010, 7, 278-290. [CrossRef]

5. Kramar, R. Beyond strategic human resource management: Is sustainable human resource management the next approach? Int. J. Hum. Resour. Manag. 2014, 25, 1069-1089. [CrossRef]

6. Renwick, D.W.; Redman, T.; Maguire, S. Green human resource management: A review and research agenda. Int. J. Manag. Rev. 2013, 15, 1-14. [CrossRef]

7. Renwick, D.W.; Jabbour, C.J.; Muller-Camen, M.; Redman, T.; Wilkinson, A. Contemporary developments in Green (environmental) HRM scholarship. Int. J. Hum. Resour. Manag. 2016, 27, 114-128. [CrossRef]

8. Rothenberg, S.; Hull, C.E.; Tang, Z. The impact of human resource management on corporate social performance strengths and concerns. Bus. Soc. 2017, 56, 391-418. [CrossRef]

9. Opoku-Dakwa, A.; Chen, C.C.; Rupp, D.E. CSR initiative characteristics and employee engagement: An impact-based perspective. J. Organ. Behav. 2018, 39, 580-593. [CrossRef]

10. Macke, J.; Genari, D. Systematic literature review on sustainable human resource management. J. Clean. Prod. 2019, 208, 806-815. [CrossRef]

11. Dao, V.; Langella, I.; Carbo, J. From green to sustainability: Information Technology and an integrated sustainability framework. J. Strateg. Inf. Syst. 2011, 20, 63-79. [CrossRef]

12. Cropanzano, R.; Mitchell, M.S. Social exchange theory: An interdisciplinary review. J. Manag. 2005, 31, 874-900. [CrossRef]

13. Gouldner, H.P. Dimensions of organizational commitment. Adm. Sci. Q. 1960, 4, 468-490. [CrossRef]

14. Blau, P.M. Social exchange. Int. Encycl. Soc. Sci. 1968, 7, 452-457. [CrossRef]

15. Saks, A.M. Antecedents and consequences of employee engagement. J. Manag. Psychol. 2006, 21, 600-619. [CrossRef]

16. Gould-Williams, J. HR practices, organizational climate and employee outcomes: Evaluating social exchange relationships in local government. Int. J. Hum. Resour. Manag. 2007, 18, 1627-1647. [CrossRef]

17. Allen, D.G.; Shore, L.M.; Griffeth, R.W. The role of perceived organizational support and supportive human resource practices in the turnover process. J. Manag. 2003, 29, 99-118. [CrossRef]

18. Liden, R.C.; Wayne, S.J.; Kraimer, M.L.; Sparrowe, R.T. The dual commitments of contingent workers: An examination of contingents' commitment to the agency and the organization. J. Organ. Behav. Int. J. Ind. Occup. Organ. Psychol. Behav. 2003, 24, 609-625. [CrossRef]

19. Nishii, L.H.; Lepak, D.P.; Schneider, B. Employee attributions of the "why" of HR practices: Their effects on employee attitudes and behaviors, and customer satisfaction. Pers. Psychol. 2008, 61, 503-545. [CrossRef]

20. Anand, S.; Vidyarthi, P.R.; Liden, R.C.; Rousseau, D.M. Good citizens in poor-quality relationships: Idiosyncratic deals as a substitute for relationship quality. Acad. Manag. J. 2010, 53, 970-988. [CrossRef]

21. Kuvaas, B. An exploration of how the employee-organization relationship affects the linkage between perception of developmental human resource practices and employee outcomes. J. Manag. Stud. 2008, 45, 1-25. [CrossRef]

22. Kuvaas, B.; Dysvik, A. Does best practice HRM only work for intrinsically motivated employees? Int. J. Hum. Resour. Manag. 2010, 21, 2339-2357. [CrossRef]

23. Cropanzano, R.; Rupp, D.E.; Byrne, Z.S. The relationship of emotional exhaustion to work attitudes, job performance, and organizational citizenship behaviors. J. Appl. Psychol. 2003, 88, 160. [CrossRef] 
24. Sanders, K.; Dorenbosch, L.; de Reuver, R. The impact of individual and shared employee perceptions of HRM on affective commitment: Considering climate strength. Pers. Rev. 2008, 37, 412-425. [CrossRef]

25. Nabi, G.R. The relationship between HRM, social support and subjective career success among men and women. Int. J. Manpow. 2001, 22, 457-474. [CrossRef]

26. Stumpf, S.A.; Doh, J.P.; Tymon, W.G., Jr. The strength of HR practices in India and their effects on employee career success, performance, and potential. Hum. Resour. Manag. 2010, 49, 353-375. [CrossRef]

27. Alshaikhmubarak, A.; Da Camara, N.; Baruch, Y. The impact of high-performance human resource practices on the research performance and career success of academics in Saudi Arabia. Career Dev. Int. 2020, 25, 671-690. [CrossRef]

28. De Cuyper, N.; De Witte, H. The management paradox: Self-rated employability and organizational commitment and performance. Pers. Rev. 2011, 40, 152-172. [CrossRef]

29. Van Harten, J.; De Cuyper, N.; Guest, D.; Fugate, M.; Knies, E.; Forrier, A. Introduction to special issue on HRM and employability: Mutual gains or conflicting outcomes? Eur. J. Work Organ. Psychol. 2020, 31, 1-15. [CrossRef]

30. Akkermans, J.; Tims, M.; Beijer, S.; De Cuyper, N. Should employers invest in employability? Examining employability as a mediator in the HRM-commitment relationship. Front. Psychol. 2019, 10, 1-10. [CrossRef] [PubMed]

31. De Vos, A.; De Clippeleer, I.; Dewilde, T. Proactive career behaviours and career success during the early career. J. Occup. Organ. Psychol. 2009, 82, 761-777. [CrossRef]

32. Schrimpf, M.; Froehlich, D.; Covarrubias Venegas, E.B. HRM Policies' Impact on Employees' Employability: The Role of Age Climate and the Offering of Developmental Measures. Adm. Sci. 2021, 11, 2-12. [CrossRef]

33. Fugate, M.; Kinicki, A.J.; Ashforth, B.E. Employability: A psycho-social construct, its dimensions and applications. J. Vocat. Behav. 2004, 65, 14-38. [CrossRef]

34. Lo Presti, A.; Ingusci, E.; Magrin, M.E.; Manuti, A.; Scrima, F. Employability as a compass for career success: Development and initial validation of a new multidimensional measure. Int. J. Train. Dev. 2019, 23, 253-275. [CrossRef]

35. Van der Heijde, C.M.V.D.; Van Der Heijden, B.I. A competence-based and multidimensional operationalization and measurement of employability. Hum. Resour. Manag. 2016, 45, 449-476. [CrossRef]

36. Forrier, A.; Verbruggen, M.; De Cuyper, N. Integrating different notions of employability in a dynamic chain: The relationship between job transitions, movement capital and perceived employability. J. Vocat. Behav. 2015, 89, 56-64. [CrossRef]

37. Rothwell, A.; Arnold, J. Self-perceived employability: Development and validation of a scale. Pers. Rev. 2007, 36, 23-41. [CrossRef]

38. Van Dam, J.E.; van den Oever, M.J.; Keijsers, E.R. Production process for high density high performance binderless boards from whole coconut husk. Ind. Crop. Prod. 2004, 20, 97-101. [CrossRef]

39. McQuaid, R.W.; Lindsay, C. The concept of employability. Urban Stud. 2005, 42, 197-219. [CrossRef]

40. De Cuyper, N.; Van der Heijden, B.I.; De Witte, H. Associations between perceived employability, employee well-being, and its contribution to organizational success: A matter of psychological contracts? Int. J. Hum. Resour. Manag. 2011, 22, 1486-1503. [CrossRef]

41. Nelissen, J.; Forrier, A.; Verbruggen, M. Employee development and voluntary turnover: Testing the employability paradox. Hum. Resour. Manag. J. 2017, 27, 152-168. [CrossRef]

42. Vanhercke, D.; De Cuyper, N.; Peeters, E.; De Witte, H. Defining perceived employability: A psychological approach. Pers. Rev. 2014, 43, 592-605. [CrossRef]

43. Clarke, M. Rethinking graduate employability: The role of capital, individual attributes and context. Stud. High. Educ. 2018, 43, 1923-1937. [CrossRef]

44. Guest, D.; Conway, N. The impact of HR practices, HR effectiveness and a 'strong HR system'on organisational outcomes: A stakeholder perspective. Int. J. Hum. Resour. Manag. 2011, 22, 1686-1702. [CrossRef]

45. Huselid, M.A. The impact of human resource management practices on turnover, productivity, and corporate financial performance. Acad. Manag. J. 1995, 38, 635-672. [CrossRef]

46. Veld, M.; Semeijn, J.; van Vuuren, T. Enhancing perceived employability: An interactionist perspective on responsibilities of organizations and employees. Pers. Rev. 2015, 44, 866-882. [CrossRef]

47. Boxall, P.; Macky, K. Research and theory on high-performance work systems: Progressing the high-involvement stream. Hum. Resour. Manag. J. 2009, 19, 3-23. [CrossRef]

48. Bal, P.M.; Kooij, D.T.; De Jong, S.B. How do developmental and accommodative HRM enhance employee engagement and commitment? The role of psychological contract and SOC strategies. J. Manag. Stud. 2013, 50, 545-572. [CrossRef]

49. Nauta, A.; Van Vianen, A.; Van der Heijden, B.; Van Dam, K.; Willemsen, M. Understanding the factors that promote employability orientation: The impact of employability culture, career satisfaction, and role breadth self-efficacy. J. Occup. Organ. Psychol. 2009, 82, 233-251. [CrossRef]

50. Baloch, Q.B.; Ali, N.; Kiani, T.S.; Ahsan, A.; Mufty, A. Relationship between HR Practices and perceived employees' performance of bankers in NWFP, Pakistan: An Empirical Evidence. Eur. J. Soc. Sci. 2010, 18, 210-214. [CrossRef]

51. Quresh, T.M.; Akbar, A.; Khan, M.A.; Sheikh, R.A.; Hijazi, S.T. Do human resource management practices have an impact on financial performance of banks? Afr. J. Bus. Manag. 2010, 4, 1281-1288.

52. Organ, D.W. Organizational Citizenship Behavior: The Good Soldier Syndrome; Lexington Books/DC Heath and Company: Lexington, MA, USA, 1988. 
53. Purcell, J.; Kinnie, N.; Hutchinson, S.; Rayton, B.; Swart, J. Understanding the People and Performance link: Unlocking the Black Box; CIPD: London, UK, 2003; ISBN 9780852929872.

54. Organ, D.W.; Podsakoff, P.M.; MacKenzie, S.B. Organizational Citizenship Behavior: Its Nature, Antecedents, and Consequences; SAGE Publication: New Delhi, India, 2006; ISBN 978-0761929963.

55. Sun, L.Y.; Aryee, S.; Law, K.S. High-performance human resource practices, citizenship behavior, and organizational performance: A relational perspective. Acad. Manag. J. 2007, 50, 558-577. [CrossRef]

56. Snape, E.; Redman, T. HRM practices, organizational citizenship behaviour, and performance: A multi-level analysis. J. Manag. Stud. 2010, 47, 1219-1247. [CrossRef]

57. Husin, S.; Chelladurai, P.; Musa, G. HRM practices, organizational citizenship behaviors, and perceived service quality in golf courses. J. Sport Manag. 2012, 26, 143-158. [CrossRef]

58. Fu, Y.K. High-performance human resource practices moderate flight attendants' organizational commitment and organizational citizenship behavior. Soc. Behav. Personal. Int. J. 2013, 41, 1195-1208. [CrossRef]

59. Wei, M.; Liao, K.Y.-H.; Chao, R.C.-L.; Mallinckrodt, B.; Tsai, P.-C.; Botello-Zamarron, R. Minority stress, perceived bicultural competence, and depressive symptoms among ethnic minority college students. J. Couns. Psychol. 2010, 57, 411-422. [CrossRef]

60. Baptiste, N.R. Tightening the link between employee wellbeing at work and performance: A new dimension for HRM. Manag. Decis. 2008, 46, 284-309. [CrossRef]

61. Noor, A. Examining organizational citizenship behavior as the outcome of organizational commitment: A study of universities teachers of Pakistan. In Proceedings of the 2nd CBRC, Lahore, Pakistan, 14 November 2009; p. 14.

62. Spurk, D.; Abele, A.E.; Volmer, J. The Career Satisfaction Scale: Longitudinal measurement invariance and latent growth analysis. J. Occup. Organ. Psychol. 2011, 84, 315-326. [CrossRef]

63. Arthur, M.B.; Khapova, S.N.; Wilderom, C.P. Career success in a boundaryless career world. J. Organ. Behav. Int. J. Ind. Occup. Organ. Psychol. Behav. 2005, 26, 177-202. [CrossRef]

64. Lo Presti, A.; Pluviano, S. Looking for a route in turbulent waters: Employability as a compass for career success. Organ. Psychol. Rev. 2016, 6, 192-211. [CrossRef]

65. Noe, R.A.; Hollenbeck, J.R.; Gerhart, B.; Wright, P.M. Fundamentals of Human Resource Management; McGraw-Hill: Portland, OR, USA, 2011; ISBN 9781260079173.

66. Xing, Y.; Liu, Y.; Tarba, S.; Cooper, S.C.L. Servitization in Mergers and Acquisitions. Intern. J. Prod. Econ. 2016, 192, 4-29. [CrossRef]

67. Tan, C.L.; Nasurdin, A.M. Human Resource Management Practices And Organizational Innovation: An Empirical Study In Malaysia. J. Appl. Bus. Res. 2010, 26, 105-116. [CrossRef]

68. Amin, M.; Ismail, W.K.W.; Rasid, S.Z.A.; Selemani, R.D.A. The impact of human resource management practices on performance: Evidence from a Public University. TQM J. 2014, 26, 125-142. [CrossRef]

69. Hall, D.T.; Chandler, D.E. Psychological success: When the career is a calling. J. Organ. Behav. Int. J. Ind. Occup. Organ. Psychol. Behav. 2005, 26, 155-176. [CrossRef]

70. Heslin, P.; Keating, L.; Minbashian, A. How Situational Cues and Mindset Dynamics Shape Personality Effects on Career Outcomes. J. Manag. 2018, 45, 2101-2131. [CrossRef]

71. Spurk, D.; Hirschi, A.; Dires, N. Antecedents and Outcomes of Objective Versus Subjective Career Success: Competing Perspectives and Future Directions. J. Manag. 2019, 45, 35-69. [CrossRef]

72. Halbesleben, J.R.; Neveu, J.P.; Paustian-Underdahl, S.C.; Westman, M. Getting to the "COR" understanding the role of resources in conservation of resources theory. J. Manag. 2014, 40, 1334-1364. [CrossRef]

73. Hogan, R.; Chamorro-Premuzic, T.; Kaiser, R.B. Employability and career success: Bridging the gap between theory and reality. Ind. Organ. Psychol. 2013, 6, 3-16. [CrossRef]

74. Mäkikangas, A.; De Cuyper, N.; Mauno, S.; Kinnunen, U. A longitudinal person-centred view on perceived employability: The role of job insecurity. Eur. J. Work Organ. Psychol. 2013, 22, 490-503. [CrossRef]

75. Van der Heijden, B.I.; de Lange, A.H.; Demerouti, E.; Van der Heijde, C.M. Age effects on the employability-career success relationship. J. Vocat. Behav. 2009, 74, 156-164. [CrossRef]

76. Nicholson, N.; De Waal-Andrews, W. Playing to win: Biological imperatives, self-regulation, and trade-offs in the game of career success. J. Organ. Behav. Int. J. Ind. Occup. Organ. Psychol. Behav. 2005, 26, 137-154. [CrossRef]

77. Lo Presti, A.; Magrin, M.E.; Ingusci, E. Employability as a Compass for Career Success: A Time-lagged Test of a Causal Model. Int. J. Train. Dev. 2020, 24, 301-320. [CrossRef]

78. Guest, D.; King, Z. Power, innovation and problem-solving: The personnel managers' three steps to heaven? J. Manag. Stud. 2004, 41, 401-423. [CrossRef]

79. Ng, T.W.; Eby, L.T.; Sorensen, K.L.; Feldman, D.C. Predictors of objective and subjective career success: A meta-analysis. Pers. Psychol. 2005, 58, 367-408. [CrossRef]

80. Sturges, J.; Conway, N.; Guest, D.; Liefooghe, A. Managing the career deal: The psychological contract as a framework for understanding career management, organizational commitment and work behavior. J. Organ. Behav. Int. J. Ind. Occup. Organ. Psychol. Behav. 2005, 26, 821-838. [CrossRef]

81. Bateman, T.S.; Crant, J.M. The proactive component of organizational behavior: A measure and correlates. J. Organ. Behav. 1993, 14, 103-118. [CrossRef] 
82. Parker, S.K.; Collins, C.G. Taking stock: Integrating and differentiating multiple proactive behaviors. J. Manag. $2010,36,633-662$. [CrossRef]

83. Thompson, M.; Heron, P. Management capability and high performance work organization. Int. J. Hum. Resour. Manag. 2005, 16, 1029-1048. [CrossRef]

84. Seibert, S.E.; Crant, J.M.; Kraimer, M.L. Proactive personality and career success. J. Appl. Psychol. 1999, 84, 416-427. [CrossRef] [PubMed]

85. Seibert, S.E.; Kraimer, M.L.; Crant, J.M. What do proactive people do? A longitudinal model linking proactive personality and career success. Pers. Psychol. 2001, 54, 845-874. [CrossRef]

86. Grant, A.M.; Parker, S.; Collins, C. Getting credit for proactive behavior: Supervisor reactions depend on what you value and how you feel. Pers. Psychol. 2009, 62, 31-55. [CrossRef]

87. Gould-Williams, J.; Davies, F. Using social exchange theory to predict the effects of HRM practice on employee outcomes: An analysis of public sector workers. Public Manag. Rev. 2005, 7, 1-24. [CrossRef]

88. Berntson, E.; Marklund, S. The relationship between perceived employability and subsequent health. Work Stress 2007, 21, 279-292. [CrossRef]

89. Podsakoff, P.M.; MacKenzie, S.B.; Moorman, R.H.; Fetter, R. Transformational leader behaviors and their effects on followers' trust in leader, satisfaction, and organizational citizenship behaviors. Leadersh. Q. 1990, 1, 107-142. [CrossRef]

90. Lo Presti, A.; Elia, A. Is the project manager's road to success paved only with clear career paths? A dominance analysis of the additive contributions of career attitudes and employability factors. Proj. Manag. J. 2020, 51, 199-213. [CrossRef]

91. Hu, L.T.; Bentler, P.M. Cutoff criteria for fit indexes in covariance structure analysis: Conventional criteria versus new alternatives. Struct. Equ. Model. A Multidiscip. J. 1999, 6, 1-55. [CrossRef]

92. Bandalos, D.L. Relative performance of categorical diagonally weighted least squares and robust maximum likelihood estimation. Struct. Equ. Model. A Multidiscip. J. 2001, 21, 102-116. [CrossRef]

93. Raeder, S.; Wittekind, A.; Inauen, A.; Grote, G. Testing a psychological contract measure in a Swiss employment context. Swiss J. Psychol. Schweiz. Z. Für Psychol. Rev. Suisse De Psychol. 2009, 68, 177-188. [CrossRef]

94. Forrier, A.; Sels, L.; Stynen, D. Career mobility at the intersection between agent and structure: A conceptual model. J. Occup. Organ. Psychol. 2009, 82, 739-759. [CrossRef]

95. Van Der Heijden, B.; Boon, J.; Van der Klink, M.; Meijs, E. Employability enhancement through formal and informal learning: An empirical study among Dutch non-academic university staff members. Int. J. Train. Dev. 2003, 13, 19-37. [CrossRef]

96. De Vos, A.; De Hauw, S.; Van der Heijden, B.I. Competency development and career success: The mediating role of employability. J. Vocat. Behav. 2011, 79, 438-447. [CrossRef]

97. Arthur, J.B. Effects of human resource systems on manufacturing performance and turnover. Acad. Manag. J. 1994, 37, 670-687. [CrossRef]

98. Briscoe, J.P.; Finkelstein, L.M. The "new career" and organizational commitment: Do boundaryless and protean attitudes make a difference? Career Dev. Int. 2009, 14, 242-260. [CrossRef]

99. Inkson, K.; Gunz, H.; Ganesh, S.; Roper, J. Boundaryless careers: Bringing back boundaries. Organ. Stud. 2012, 33, 323-340. [CrossRef]

100. Anderson, J.C.; Rungtusanatham, M.; Schroeder, R.G. A theory of quality management underlying the Deming management method. Acad. Manag. Rev. 1994, 19, 472-509. [CrossRef]

101. Elrehail, A.; Emeagwali, L.; Alsaad, A.; Alzghoul, A. The impact of Transformational and Authentic leadership on innovation in higher education: The contingent role of knowledge sharing. Telemat. Inform. 2018, 35, 55-67. [CrossRef]

102. Latorre, F.; Guest, D.; Ramos, J.; Gracia, F.J. High commitment HR practices, the employment relationship and job performance: A test of a mediation model. Eur. Manag. J. 2016, 34, 328-337. [CrossRef]

103. Veth, P.; Ward, I.; Manne, T.; Ulm, S.; Ditchfield, K.; Dortch, J.; Kendrick, P. Early human occupation of a maritime desert, Barrow Island, North-West Australia. Quat. Sci. Rev. 2017, 168, 19-29. [CrossRef]

104. Baruch, Y.; Peiperl, M. Career management practices: An empirical survey and implications. Hum. Resour. Manag. 2000, 39, 347-366. [CrossRef]

105. Vinkenburg, C.J.; Weber, T. Managerial career patterns: A review of the empirical evidence. J. Vocat. Behav. 2012, 80, 592-607. [CrossRef]

106. Bagdadli, S.; Gianecchini, M. HRM/Organizational Career Management Systems and Practices; Gunz, H., Lazarova, M., Mayrhofer, W., Eds.; The Routledge Companion to Career Studies; Routledge: London, UK, 2020; pp. 365-381, ISBN 9781315674704.

107. Clarke, M. The organizational career: Not dead but in need of redefinition. Int. J. Hum. Resour. Manag. 2013, $24,684-703$. [CrossRef]

108. De Vos, A.; Cambré, B. Career management in high-performing organizations: A set-theoretic approach. Hum. Resour. Manag. 2017, 56, 501-518. [CrossRef]

109. Arthur, M.B.; Rousseau, D.M. The Boundaryless Career: A New Employment Principle for a New Organizational Era; University Press: Oxford, UK, 2001; ISBN 978-0195149586.

110. Tomlinson, J.; Baird, M.; Berg, P.; Cooper, R. Flexible careers across the life course: Advancing theory, research and practice. Hum. Relat. 2018, 71, 4-22. [CrossRef] 
111. Fugate, M.; Kinicki, A.J. A dispositional approach to employability: Development of a measure and test of implications for employee reactions to organizational change. J. Occup. Organ. Psychol. 2008, 81, 503-527. [CrossRef]

112. Podsakoff, N.P.; Whiting, S.W.; Podsakoff, P.M.; Blume, B.D. Individual-and organizational-level consequences of organizational citizenship behaviors: A meta-analysis. J. Appl. Psychol. 2009, 94, 122. [CrossRef]

113. Podsakoff, P.M.; MacKenzie, S.B.; Lee, J.Y.; Podsakoff, N.P. Common method biases in behavioral research: A critical review of the literature and recommended remedies. J. Appl. Psychol. 2003, 88, 879. [CrossRef] [PubMed]

114. Caligiuri, P.; De Cieri, H.; Minbaeva, D.; Verbeke, A.; Zimmermann, A. International HRM insights for navigating the COVID-19 pandemic: Implications for future research and practice. Nat. Public Health Emerg. Collect. 2020, 51, 1-17. [CrossRef]

115. Manuti, A. Migrants' Human Capital in the Workplace: Challenges and Opportunities for a People-Based Strategic Human Resource Management. In Health, Safety and Well-being of Migrant Workers: New Hazards, New Workers; Springer: Cham, Switzerland, 2020; pp. 43-59. [CrossRef] 